\title{
Experimental Investigations of Effect of LC-circuits on Sparking and Thermal State of Sliding Electric Contact Unit
}

\author{
Oksana Kozyreva, Igor Plokhov, Nikita Kotkov, Igor Savraev, Alexander Ilyin \\ Pskov State University, Computer Science and Electric Power Engineering Faculty. \\ Address: Russian Federation, Pskov, Lenin square, 2.
}

\begin{abstract}
. such processes in electric machines having sliding contacts as sparking and overheating can be the reason of the deep electroerosive wear. Searching effective ways to reduce sparking has an obvious practical significance since it extends the service life of the sliding contact in particular and service life of the electro-mechanic units in whole.

This article contains information about physical processes in the electrical sliding contact. The method of spark suppression related to LC filters introduced to the electromagnetic brush circuits is considered, the device for spark reducing is suggested. The calculations of the impact of the device for spark reducing on sparking and thermal processes in the contact pairs are described.
\end{abstract}

Keywords: electrical machines, turbogenerator, thermal processes, sparking, brush contacts.

\section{INTRODUCTION}

Electric sliding contact (SC) is widely used in electric machines and apparatus for such purpose as current transfer (both direct and alternating) from the fixed contact points to the parts in motion.

When sliding contacts are applied in electric machines, such processes as sparking and overheating the contacts can be the reason of deep electroerosive wear. These processes can be caused by several factors. The main factors are the mechanic SC contacting instability and the processes occurring in the electromagnetic circuits of the SC, which cause high-frequency overcurrents and overvoltages.

Searching effective ways to reduce sparking has an obvious practical significance since it extends the service life of the SC in particular and service life of the electro-mechanic units in whole. One of the effective methods of spark suppression (electromagnetic interference, thermal stress reducing) in the $\mathrm{SC}$ is the method related to the development of LC filters introduced to the electromagnetic brush circuits. For example in the works of I.V. Plokhov [1] the capacitance was connected between one isolated brush on the slip ring and the group of working brushes. The device was developed for reducing sparking in sliding electric contact units having slip rings and for applying in turbo generators.

In the works of F.Veselka [2], [3] it was suggested to use supplementary capacitance and inductance couplings for the spark suppression by applying electrically conductive film coatings to the surfaces of each brush and brush holder (for the DC commutator motor). Furthermore at the Electric Drive and Automation Systems Department of Pskov State University the modification of the construction of SC unit was proposed. The modification includes adding the inductive and capacitive elements to the electromagnetic circuit of the SC. The device for spark reducing (DSR) in the sliding electric contact unit was patented [4].

\section{MATERIALS AND METHODS}

Investigations of electric contacts thermal design were began by R. Holm and continued by a number of researches [5]-[8], these investigations consider the particular cases of the SC thermal conductivity boundary value problems. In the 70-s - 90-s a number of scientific researches were devoted to in-depth investigations of the physical dependences of the electro-frictional interaction [8]-[11]. In these investigations the attempts of mathematical formulation of the nonstationary dynamic modes of the electro-frictional interaction is given for the first time.

The modern explanation of the physical processes in the sliding electric contact is summarized to the following. In the contact of two rough bodies the total interface (sliding surface) is split into a number of spots ( $\alpha$-spots). Therefore when the flow of energy passes through this surface it has to overcome an additional resistance caused by the violation of the flow lines homogeneousness - it is called constriction resistance. This resistance is summed with the resistance of oxide films in general case. In addition to this resistances there are some films consisted of http://dx.doi.org/ 10.17770/etr2017vol3.2575 
wear products on the contact surfaces, and this wear products do not react chemically with the contact material.

In the area of direct surface-to-surface mechanical contact (transition layer) commutating occurs in hightemperature thermal spikes caused by the flow of the electric current through the conductive $\alpha$-spots (areas of constriction of the electric current and of the heat flow). Bad commutating can occur in an electric arc, and then the areas of conductivity can be melted, if the action is prolonged, it causes the significant increase in the overall transition layer and brush temperature. Thus it can be seen that there is more significant heat release in the contact area in the sparking brush in comparison with the brush without sparking (Fig. 1).
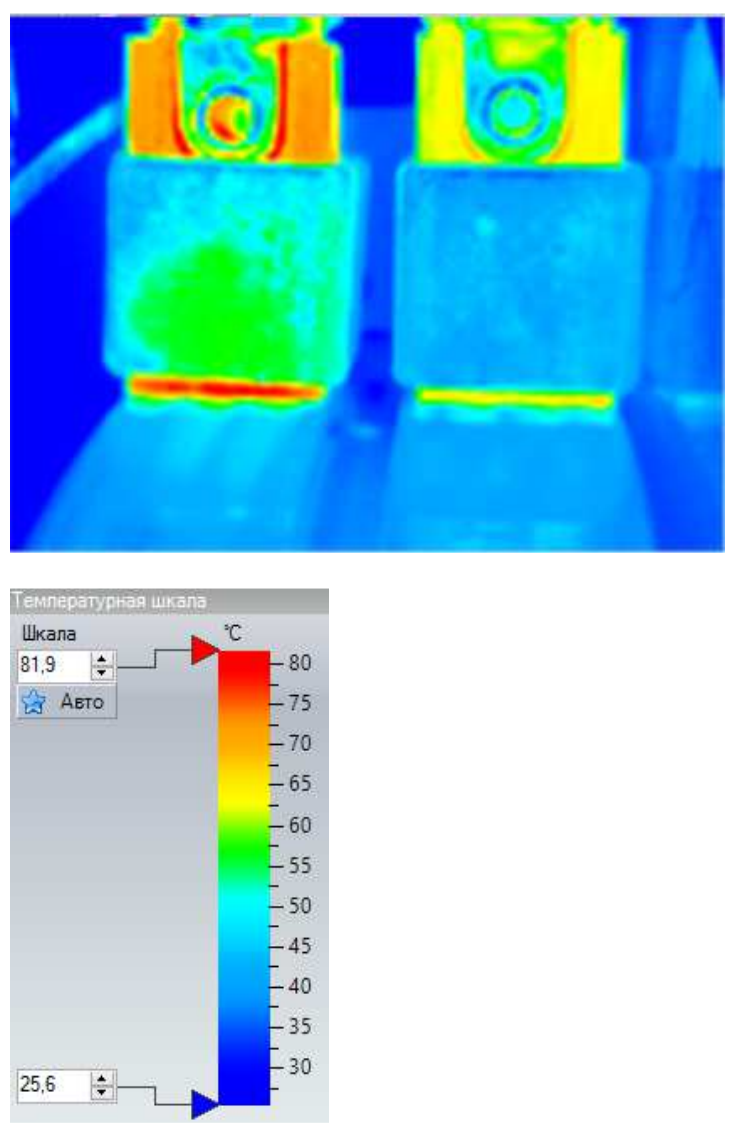

Fig.1. Thermograms during the experiment: a) for sparking brush b) brush without sparking during the process. Thermograms testify to a higher heating the contact area of the brush working with the increased sparking

Due to the process of electric current passing the constriction resistance, the Joule heat is released; in addition to this heat there is a thermal power caused by the friction between the bush and the slip ring. Arcing has a significant impact on the heating processes in the contact area.

In cases when the temperature of the contact surface exceeds the softening point of the brush material, the mechanical and electrical characteristics of the contact deteriorate and the brush wear becomes accelerated.

In the work of V.N. Zaboin [6] the solution of the problem of the steady-state thermal balance was proposed with a set of assumptions. Based on the Kohlrausch-Holm equations for determining the maximum temperature value in the homogeneous linear conductor or fixed electric contact and the Jaeger equation for calculating the maximum temperature value on the surface of the heat source moving along the semi-infinite surface [6], [7], the expression for calculating the maximum temperature inside the element having a lower thermal conductivity in any contact pair was obtained. Having used the calculation formula [6], one can obtain the table of temperature and losses distributions for the elements of different contact pairs. The values of the maximum temperatures in the contacts of the different brushes are given in the Table 1 .

\begin{tabular}{|c|c|c|c|c|}
\multicolumn{5}{c|}{ Table 1. } \\
\hline $\begin{array}{c}\text { Type of } \\
\text { brush }\end{array}$ & $\begin{array}{c}\text { ЭГ2AФ } \\
\text { (EG2AF) } \\
\text { (electro- } \\
\text { graphite) }\end{array}$ & $\begin{array}{c}\text { ЭГ2AФ } \\
(\mathrm{EG} 2 \mathrm{AF}) \\
\text { (electro- } \\
\text { graphite) }\end{array}$ & $\begin{array}{c}\text { MГCO } \\
\text { (MGSO) } \\
\text { (copper- } \\
\text { graphite) }\end{array}$ & $\begin{array}{c}\text { MГCO } \\
\text { (MGSO) } \\
\text { (copper- } \\
\text { graphite) }\end{array}$ \\
\hline Slip ring & Steel & Copper & Steel & Copper \\
\hline $\mathrm{Q}_{\max },{ }^{\circ} \mathrm{C}$ & 513 & 122 & 300 & 72 \\
\hline
\end{tabular}

As can be seen from the table, for example, the maximum temperature in the SC in the contact pair of the brushes of ЭГ $2 А Ф$ type and the steel slip rings can reach $500{ }^{\circ} \mathrm{C}$, which is close to the temperature of the recrystallization of the contact pairs.

According to the Table 1, it is possible to determine approximately the temperature ranges in the contact area during the experiments.

\section{RESULTS AND DISCUSSION}

A number of experiments at the Electric Drive and Automation Systems Department of Pskov State University were conducted. The investigations included the calculate of impact the device for spark reducing (DSR) on sparking and thermal processes in the contact pairs.

The experimental setup of turbogenerator commutator having the contact pair: electro-graphite brushes of ЭГ 2АФ type - slip rings made of stainless steel was used for the investigations mentioned above. The device (Fig. 2) is basically the electric capacitance 5 introduced between the electrically connected in parallel brush groups 1 of one slip ring of the sliding contact unit 3 . Along with that, the first brush group is connected with the power bus 4 and the second brush group 2 is disconnected from the power bus. Moreover the electrical capacitance consists of two groups of the capacitors connected in parallel, polar 7 and non-polar 6; the non-polar group of the capacitors is connected directly to the circuit, and the second capacitor group is connected via the inductance 8 . The diode 9 is connected between the 
terminals of the polar capacitors group, and its anode should be connected to the positive terminal of the polar capacitors.

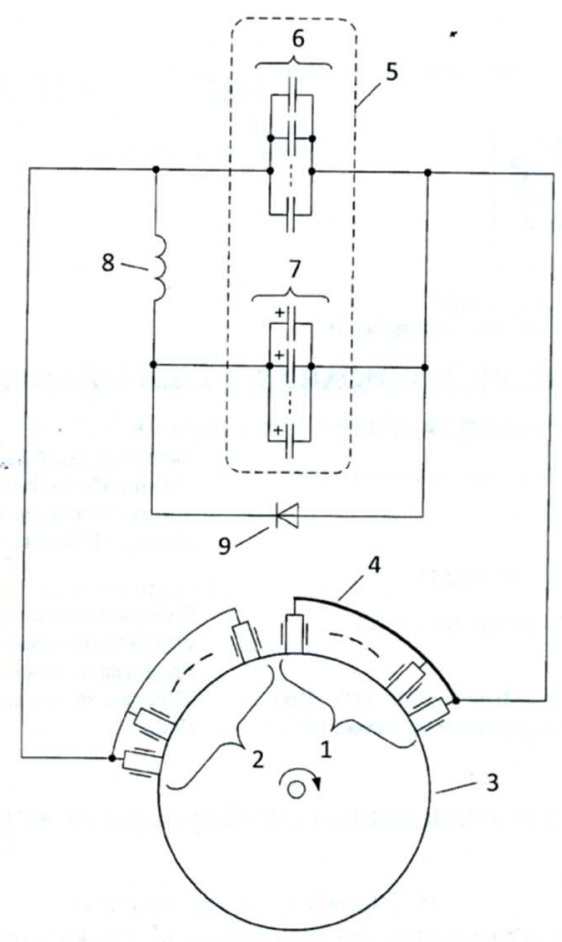

Fig.2. The device for spark reducing in the sliding electric contact unit [4].

Fig. 3 shows the curves of brushes heating obtained from the experiments while working at the sparking mode with or without using the DSR. The visual observation showed that applying the DSR allows to reduce sparking from 2 to $1 \frac{1 / 4}{4}$ points.

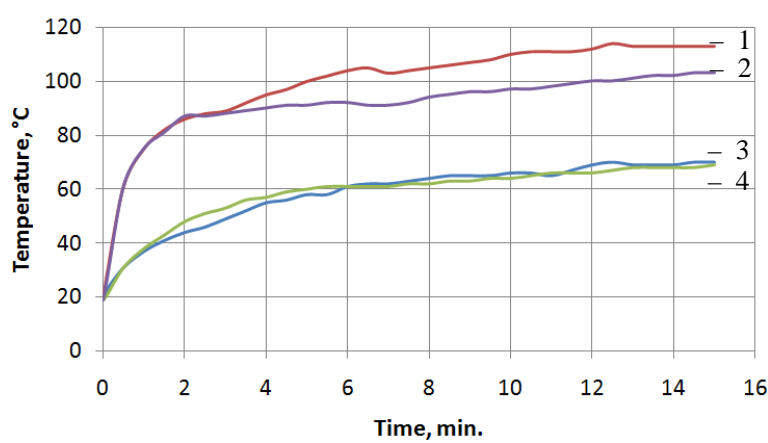

Fig.3. Anode brush and sparking cathode brush temperature dependence on time with or without applying the DSR: 1 - cathode brush, the DSR is turned off; 2 - cathode brush, the DSR is turned on; 3 - anode brush, the DSR is not connected; 4 - anode brush, the DSR is connected.

As can be seen from the graph, the sparking brush heats up much slower and reaches the lower steady state temperature when the device is turned on. As the dependences were obtained at some distance from the contact surface (at the slight distance value), the values of the temperatures after recalculating it for the area of the direct contact would be close to the values in table. However it should be taken into account that temperature of the short-term thermal spikes occurring in the transition layer can be several times higher than the average temperatures of the working contact pair. It causes melting and evaporating the brush material but there is no enough time (because of the very short duration of the single high-temperature spike) for heat transfer to the brush body. It is also necessary to take into consideration that the proportion of the heat losses removed from the lateral brush surface is about a half of the total losses in the contact [6].

In any case it can be concluded that if the temperature gradients in the brushes are equal, the contact surface of the brush having the worst commutation reaches the steady state temperature value, which is lower when the device for spark reducing is connected.

In parallel with the experiments of temperature dependences registering, the experiments of registering the voltages between the working group of brushes and the isolated brush for each temperature point were conducted (Fig. 4).
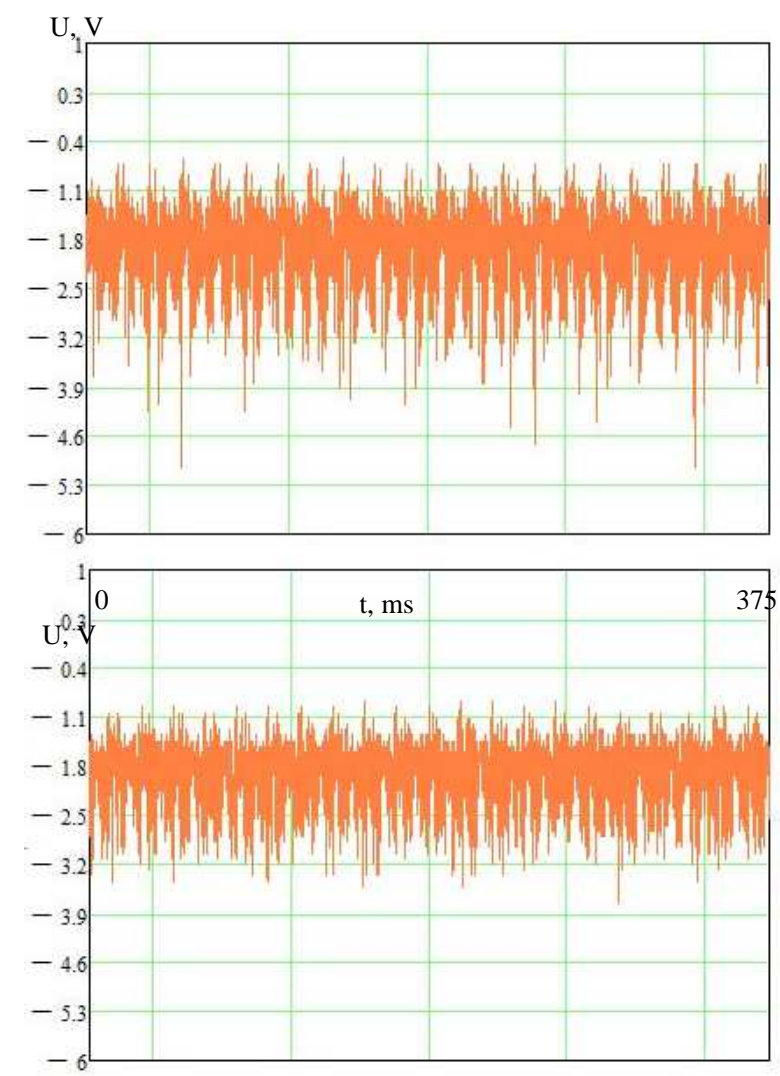

Fig 4. Dependence of cathode ${ }^{\text {ms }}$ brush voltage on time (at 5-th minute) with or without applying the DSR: the DSR is turned on (top graph), the DSR is turned off (bottom graph)

Analyzing the obtained dependencies it can be concluded that the magnitude of the transition voltage drop and the number of voltage spikes decrease due 
to the effect of the DSR on the thermal and electromagnetic process.

Basically, the main interest is in obtaining high quality dependence of the brush heating process near the transition layer for the brush working in the sliding electric contact unit of the turbogenerator (when the current comparable to the rated turbo generator current passes through the brush). The temperature dependence clearly shows the significant effect of the connected device for spark reducing on the contact pair temperature state and on the electromagnetic processes in the brush circuit consequently.

It is worth emphasizing that the small modification in the construction of the commutator electromagnetic circuit results in reducing brush sparking, decreasing the temperature of the sparking brush contact surface and, consequently, in increasing the service life of the brushes and the service life of the electric machine commutator in general.

\section{CONCLUSION}

The positive effect of the device for spark reducing in the sliding electric contact unit on the thermal and electromagnetic processes in the commutator is confirmed by the experimental investigations. Connecting the device results in reducing brush sparking and decreasing the temperature of the sliding contact.

Such modification of brush contacts as adding the devices for spark reducing to the each sliding contact allows to:

- reduce the overall level of the electromagnetic oscillations,

- reduce the intensity of the sparking process in the sliding contact and the rate of its mechanical wear the as a consequence,

- extend the overall service life of the electric machine commutator.

\section{V.ACKNOWLEDGMENTS}

This study was carried out within the one-year phase of the research work № 173 of the basic part of the Ministry of Education and Science of the Russian Federation state task №2014/700.

\section{REFERENCES}

[1] Плохов И. В. Комплексная диагностика и прогнозирование технического состояния узлов скользящего токосъёма турбогенераторов. Диссертация доктора технических наук. СПбГПУ. 2001.

[2] Забоин В.Н., Веселка Ф. Способы уменьшения искрения и износа щёток в коллекторных электрических машинах. Механика и физика процессов на поверхности и в контакте твёрдых тел, деталей технологического и энергетического оборудования. 2009, сс. 124-129.

[3] Chmelík, K. Kluzný kontakt v elektrických strojích. K. Chmelík, F. Veselka. Ostrava. KEY Publishings.r.o. 2007, c. 256.

[4] Плохов И.В., Ильин А.В., Исаков А.Н., Козырева О.И. Устройство для уменьшения искрообразования в узле скользящего токосъема. Патент на полезную модель RU132630. 2013.09.20.

[5] Мерл В. Электрический контакт. Госэнергоиздат. 1962, c. 80 .

[6] Забоин В.Н. Оценка тепловой напряжённости элементов неоднородного скользящего электрического контакта. Механика и физика фрикционного контакта и граничных слоёв. 2004, сс.129-133.

[7] Ragnar Holm, Electric Contacts Handbook, 3rd ed., Berlin, Springer-Verlag. 1958.

[8] Реутт Е.К., Саксонов И.Н. Электрические контакты. М.: Воениздат. 1971, с.126.

[9] Омельченко В.Т. Теория процессов на контактах. Харьков: ХГУ, Вища школа. Издательство при Харьковском ун-те. 1979, с. 126.

[10] Ким Е.И., Омельченко В.Т., Харин С.Н. Математические модели тепловых процессов в электрических контактах. Алма-Ата. Изд-во Наука. 1977, с. 236.

[11] Кончиц В.В., Мешков В.В., Мышкин В.В. Триботехника электрических контактов. Минск, Наука и техника. 1986.

[12] Забоин В.Н. Определение сопротивления стягивания неоднородного скользящего электрического контакта. Scientific proceedings of Riga technical university. Power and electrical engineering. 2002, cc. 77-82.

[13] Kohlrausch F. Statioarer Temperaturzustand. Ann. Phys. Lpz. № 1.1990 , cc. 134-158.

[14] Carslaw, H. S., Jaeger, J. C. Conduction of heat in solids. Second edition, Oxford. 1959. 